\title{
Effect of a 12-Week Training Program on Levels of Glucose-6- Phosphate Dehydrogenase and Antioxidant Activity
}

\author{
12 Haftalık Antrenman Programının Glukoz 6 Fosfat Dehidrogenez ve \\ Antioksidan Aktivite Düzeyi Üzerine Etkisi
}

Murat Kaldırımcı
Atatürk University, Sports High School, Erzurum, Turkey

\section{Abstract}

Objective: It has been suggested that regular, long- term exercise increases erythrocyte glucose-6- phosphate dehydrogenase (G6PD) and antioxidant enzymatic activities. The purpose of this study was to investigate whether G6PD activity and antioxidant activities consisting of glutathione peroxidase (GPX) and glutathione $s$ transferase (GST) levels changed with a 12 week aerobic exercise program in basketball players.

Materials and Methods: For baseline values, blood samples were obtained from basketball players and age and sex matched sedentary healthy volunteers. Plasma GPX, GST levels and G6PD activities were evaluated with commercial kits. Then, a 12 week training program was performed for basketball players. Pre training and post training values were compared within all groups. Results: Before training program, GPX, GST levels and G6PD activities were significantly higher in basketball players than sedentary controls ( $p<0.05, p<0.05, p<0.001$, respectively). Also G6PD activities and GPX, GST levels were significantly increased after training program. ( $p<0.05, p<0.01, p<0.01$, respectively). A positive correlation was found between G6PD activity and GPX, GST levels.

Conclusion: Our results suggest that long term- regular physical exercise increases G6PD activity and antioxidant activities and cause adaptations in antioxidant defences.

(Turk J Rheumatol 2010; 25: 34-6)

Key words: Exercise, Glucose-6-Phosphate Dehydrogenase Activity, Antioxidant Activity

Received: 24.09.2009

Accepted: 12.10 .2009

\section{Özet}

Amaç: Bu çalıșmanın amacı basketbol oyuncularında 12 haftalık aerobik egzersiz programının G6PD aktivitesi, glutation peroksidaz ve glutation $\mathrm{S}$ transveraz seviyeleri üzerine etkisi olup olmadığını araștırmak idi.

Yöntem ve Gereçler: Bașlangıç değerleri için basketbol oyuncuları ve sedanter yaș ve cins benzer sağlıklı kontroller için kan örnekleri alındı. Plazma glutation peroksidaz, glutation $\mathrm{S}$ transveraz ve G6PD aktiviteleri kitlerle değerlendirildi daha sonra basketbol oyuncularına 12 haftalık egzersiz programı uygulandı. Antrenman öncesi ve antrenman sonrası değerler tüm gruplarda karșılaștırıldı. Bulgular: Antrenman programından önce glutation peroksidaz, glutation S transveraz ve G6PD aktiviteleri basketbol oyuncularında sedanter kontrollerden anlamlı olarak yüksekti $(p<0.05$, $\mathrm{p}<0.05, \mathrm{p}<0.001)$. Antrenman programından sonra G6PD aktiviteleri, glutation peroksidaz, glutation $\mathrm{S}$ transveraz seviyeleri anlamIı olarak artmıstı $(p<0.05, p<0.01, p<0.01)$. G6PD aktivitesi ve glutation peroksidaz,glutation $S$ transveraz seviyeleri arasında pozitif bir korelasyon bulundu.

Sonuç: Sonuç olarak biz uzun süreli fiziksel egzersizlerin G6PD ve antioksidan aktiviteleri artırdığını ve antioksidan defansda adaptasyonlara neden olduğunu söyleyebiliriz.

(Turk J Rheumatol 2010; 25: 34-6)

Anahtar sözcükler: Egzersiz, glukoz 6 fosfat dehidrogenaz aktivite, antioksidan aktivite

Alındığı Tarih: 24.09.2009 Kabul Tarihi: 12.10.2009

\section{Introduction}

Physical activity increases generation of free radicals in several ways. Catecholamines that are released during exercise can lead to free radical production. Other sources of increased free radicals with exercises include prostanoid metabolism, xanthine oxidase, NAD $(\mathrm{P}) \mathrm{H}$ oxidase and several secondary sources such as the release of radicals by macrophages recruited to repair damaged tissue $(1,2)$. Free radicals are neutralized by an antioxidant defence system. Also, it has been reported that exercise causes adaptations in antioxidant defences. It has been suggested that regular, long-term exercise increases antioxidant enzymatic activities and the G6PD activity (3-5). 
The aim of the present study was to evaluate the effects of regular long-term training on the erythrocyte G6PD activity and antioxidant enzymatic activities in basketball players.

\section{Materials and Methods}

\section{Subjects}

This study was performed at the School of Physical Training and Higher Sport Education in Erzurum, Turkey. 12 male basketball players of the second Turkish League (18-23 year, mean $20.6 \pm 2.4$ years) and 11 sedentary age and sex matched controls were included in the study. These players were involved in sports as amateurs or professional for at least two years. All subjects signed the informed consent to participate in the study. Two groups were evaluated for age, height, weight and duration of sport. Subjects were nonsmokers, and did not consume alcohol. Regular menu consisted of a mixed diet of Turkish foods. None of the subjects was following a special diet. Participants were excluded if they were taking anabolic drugs, vitamins or other antioxidants. The control subjects had a sedentary lifestyle and did not practice any sport regularly. All individuals were determined as healthy based on history, clinical examination. A 12 week training program with 3 days per week was performed for basketball players. This program consisted of warm up (15 min) followed by a main part (20 to $35 \mathrm{~min}$ ) at a work intensity of $60 \%$ to $75 \%$ of peak heart rate and by a cooldown period (10 $\mathrm{min}$ ).

\section{Blood Sampling}

Venous blood samples were obtained from all subjects in two groups and from basketball players after a 12-week training program. After a $12 \mathrm{~h}$ overnight fast, venous blood was drawn from the antecubital vein and was collected in to vacutainer tubes with $\mathrm{k}_{3}$-EDTA as anticoagulant $(1 / 10, \mathrm{~L} / \mathrm{L})$. The samples centrifuged at $3000 \mathrm{xg}$ for $15 \mathrm{~min}$ and plasma was removed by a pasteur pipette.

\section{Biochemical Measuments}

By measuring the absorbance change per minute and by using the molar extinction coefficient of NADPH, GPX activity was calculated and expressed as IU/L. GST activity was also determined at $340 \mathrm{~nm}$ with 1, 2-dichloro-4- nitrobenzene as substrate and expressed as IU/L. Biochemical evaluations were carried out using a CECIL CE 3041, (Cambridge, UK) spectrophotometer. We used the kinetic UV determination in serum plasma and erythrocytes for in vitro diagnostic use only, employing the haemoglobin $(\mathrm{Hb})$ normalization procedure invented and recommended by the manufacturer. The selected kit offers a rapid quantitative measurement of G6PD activity coupled to a simultaneous evaluation of the haemoglobin content in the same sample, expressing results in units/gram haemoglobin (U/g Hb).

\section{Statistical analysis}

The statistical analysis was performed by means of the SPSS 11.0 for Windows program. Data were presented as means $\pm S D$ and independent samples $t$ test was used to analyse the data between two groups and $p<0.05$ was considered as statistically significant.

\section{Results}

Demographic features as age, body mass index (BMI), height, duration of sport and GPX,GST and G6PD activities as indicators of antioxidant defence mechanism in basketball players and non-sporting controls are shown in Table 1. Both groups had similar age and BMI values and there was no significant difference between groups. GPX, GST and G6PD activities were significantly higher in basketball players than sedentary controls $(p<0.05, p<0.05$ and $p<0.01$ respectively). These values were significantly increased after a 12 weekly training program $(p<0.05, p<0.01, p<0.01$, respectively) (Table 2). A positive correlation was found between G6PD activity and GPX, GST levels. G6PD activity positively correlated with GPX $(r=0.69, p<0.001)$ and GST $(r=0.71, p<0.001)$ levels.

\section{Discussion}

It is well known that regular physical exercise and sport performance are beneficial. Several studies consistently showed that physical exercise may induce oxidative stress in both humans and experimental animals $(5,6)$. In recent years, it was been documented that free oxygen radicals induced by acute exercise were involved in damage to muscles and other tissues. Increased levels of the products of oxidative damage are observed in blood and tissues

Table 1. Demographic features and GPX, GST and G6PD activities of basketball players and controls

\begin{tabular}{lcc}
\hline & $\begin{array}{c}\text { Sportsmen } \\
\text { (mean } \pm \text { standart } \\
\text { deviation) }\end{array}$ & $\begin{array}{c}\text { Control } \\
\text { (mean } \pm \text { standart } \\
\text { deviation) }\end{array}$ \\
\hline Age (years) & $22.3 \pm 2.3$ & $22.1 \pm 2.2$ \\
Height (cm) & $184 \pm 5.07$ & $173 \pm 4.62$ \\
BMI (kg/m²) & $24.78 \pm 2.75$ & $25.32 \pm 4.03$ \\
Duration Of sport (years) & $5.6 \pm 1.4$ & \\
G6PD (U/g Hb) & $8.01 \pm 1.85$ & $5.96 \pm 1.75^{* *}$ \\
GPX (IU/L) & $4.69 \pm 1.16$ & $3.68 \pm 1.05^{*}$ \\
GST (IU/L) & $6.41 \pm 1.11$ & $4.96 \pm 1.00^{* *}$ \\
\hline${ }^{*} \mathrm{p}<0.05, * *$ p $<0.01$ & & \\
BMI: body mass index, G6PD: glucose-6- phosphate dehydrogenase, \\
GPX: glutathione peroxidase, GST: glutathione $s$ transferase
\end{tabular}

Table 2. G6PD, GPX and GST activities after a 12 week training program

\begin{tabular}{lc}
\hline & (mean \pm standart deviation) \\
\hline G6PD (U/g Hb) & $11.4 \pm 1.80^{* *}$ \\
GPX (IU/L) & $6.01 \pm 1.69 *$ \\
GST (IU/L) & $8.94 \pm 1.74 * *$ \\
\hline$* p<0.05, * * p<0.01$ & \\
BMI: body mass index, G6PD: glucose-6- phosphate dehydrogenase, \\
GPX: glutathione peroxidase, GST: glutathione $s$ transferase
\end{tabular}


after acute exercise. This is apparently contradictory to the beneficial effects of exercise $(1,4,5,7,8)$. However, several studies have shown that long-term regular exercise has a protective effect on oxidative stress. It was been showed that training reduces production of lipid peroxide products and prevents oxidative damage in tissues by inducing the antioxidant system in sports. Many studies have investigated the relation between exercise and antioxidant capacity. Antioxidant enzymes include superoxide dismutase, glutathione peroxidise and catalase. The main non-enzymatic antioxidants include glutathione, vitamins $A, E$ and $C$ ubiquinone and flavonoids. Some of the antioxidative enzymes such as GPX and GST have been most commonly examined in exercise stress $(1,4,7-9)$.

G6PD is the first enzyme in the pentose phosphate pathway. Its most important function is to reduce nicotinamide adenine dinucleotide phosphate (NADP) to NADPH. NADPH is required as a cofactor in the reduction of oxidized glutathione (GSSH) to its reduced state (GSH) and for the reduction of mixed disulfides of glutathione and cellular proteins $(6,10)$. GSH is a source of protection against oxidative attack, where it is used by the selenium-glutathione peroxidase, system to detoxify hydrogen peroxide and organic peroxides, provided that sufficient GSH is made available (9). G6PD activity is closely related to the hydrogen peroxides as well as organic peroxides. It has been suggested that G6PD activity is lowered by acute exercise period $(4,6)$. But it is unclear whether G6PD activity changed with a long-term regular training program.

In the present study, GPX and GST levels were significantly higher in the basketball players than sedentary controls before the training program, as found by other authors. In addition, GPX, GST levels were significantly increased in the players after a 12 week training program. These findings are in agreement with the previously reported studies. The erythrocyte G6PD activity was increased in the players before training program. It was significantly augmented after a 12 weekly aerobic training program. Moreover, statistically significant positive correlations were found between G6PD activity and GPX, GST levels.

Several studies have reported that a training program increase the GPX and GST activities $(3,8,9)$. Our results were in accordance with the previously reported data from several studies. In contrast, Schulpis at al. (6) reported that G6PD activity was decreased by training probably due to free radical action in acute exercise period. The erythrocyte G6PD activity is closely related to free radical production. The role of G6PD as a antioxidant enzyme has been recognized in erythrocytes for a long time. G6PD deficiency is one of the most, X-linked genetic disease affecting an estimated 400 million people worldwide (11). The Mediterranean (3\% residual G6PD activity) and African (10-15\% G6PD residual activity) forms do not cause symptoms in otherwise healthy individuals. However the deficient phenotype may manifest on intoxications or pathological challenges $(6,12)$.

It has been suggested that individuals undergoing exercise training have high levels of antioxidant enzymes and non enzymatic antioxidants, causing a greater resis- tance to exercise- induced oxidative stress. These adaptations may result from cumulative effects of repeated exercise bouts on the gene expression of antioxidant enzymes as on exercise- induced modulation of antioxidant defence $(13,14)$. In conclusion we suggest that regular, long-term physical exercise cause adaptations in antioxidant defences. However G6PD activity should be evaluated in the sports of Mediterranean and African origin especially. Future studies would be needed to clarify the association between exercise and G6PD activity.

\section{Conflict of Interest}

No conflict of interest is declared by the authors.

\section{References}

1. Urso ML, Clarkson PM. Oxidative stress exercise, and antioxidant supplementation. Toxicology 2003; 189: 41-54.

2. Jackson MY. Free radicals in skin and muscle: damaging agents or signals for adaptation? Proc Nutr Soc 1999; 59: 673-6.

3. Melikoglu MA, Kaldirimci M, Katkat D, Sen I, Kaplan I, Senel K. The effect of regular long term training on antioxidant enzymatic activities. J Sports Med Phys Fitness 2008; 48: 388-90.

4. Illhan N, Kamanli A, Ozmerdivenli R, Ilhan N. Variable effects of exercise intensity on reduced glutathione, thiobarbituric asid reactive substance levels and glucose concentration. Arch Med Res 2004; 35: 294-300.

5. Sen CK. Oxidants and antioxidant in exercise. J Appl Physiol 1995; 79: 675-86.

6. Schulpis KH, Reclos GJ, Parthimos T, Parthimos N, Gavriilidis A, Tsakiris S. L-cysteine supplementation protects the erythrocyte glucose-6-phosphate dehydrogenase activity from reduction induced by forced training. Clin Biochem 2006; 39: 1002-6.

7. Ashton T, Young IS, Peters JR, Jones E, Jackson SK, Davies B, et al. Electron spin resonance spectroscopy, exercise, and oxidative stress: an ascorbic acid intervention study. J Appl Physiol 1999; 87: 2032-6.

8. Robertson JD, Maughan RJ, Duthie GG, Morrice PC. Increased blood antioxidant systems of runners in response to training load. Clin Sci 1991; 80: 611-8.

9. Anderson BB, Carandina G, Lucci M, Perry GM, Vullo C. Red-cell GSH regeneration and glutathione reductase activity in G6PD variants in the Ferrara area. Br J Haematol 1987; 67: 459-66.

10. Carmagnol F, Sinet PM, Jerome H. Selenium dependent and non-selenium-dependent glutathione peroxidases in human tissue extracts. Biochim Biophys Acta 1983; 759: 49-57.

11. Meloni T, Forteleoni G, Meloni GF. Marked decline of favism after neonatal glucose-6-phosphate dehydrogenase screening and health education: the northern Sardinian experience. Acta Haematol 1992; 87: 29-31.

12. Luzzatto L, Mehta A. Glucose-6-phosphate dehydrogenase deficiency. In: Scriver CR, Beaudet AL, Sly WS, Valle D, (eds). The Metabolic and Molecular Bases of Inherited Disease. New York: McGraw-Hill, 1995; 3367-98.

13. HO HY, Cheng ML, Chiu DTY. Glucose-6-phosphate dehydrogenase-from oxidative stress to cellular functions and degenerative disease. Redox Rep 2007; 12: 109-18.

14. Tsakiris S, Reclos GJ, Parthimos T, Taskiris T, Parthimos N, Schulpis $\mathrm{KH}$. alpha Tocopherol supplementation restores the reduction of erythrocyte glucose-6- phosphate dehydrogenase activity induced by forced training. Pharmacol Res 2006; 53: 373-9. 